\title{
PENGEMBANGAN PROJECTILE LAUNCHER SEBAGAI ALAT PRAKTIKUM SEDERHANA FISIKA PADA MATERI GERAK PARABOLA
}

\section{THE DEVELOPMENT OF PROJECTILE LAUNCHER AS A SIMPLE PHYSICS PRACTICUM TOOL IN PARABOLA MOTION MATERIALS}

\author{
Badru Salam $^{1}$ dan Sri Latifah ${ }^{2}$ \\ ${ }^{1}$ SMK Bhakti Wiyata Pampangan Lampung Barat \\ ${ }^{2}$ Prodi Pendidikan Fisika Fakultas Tarbiyah dan Keguruan Universitas Islam Negeri Raden Intan Lampung \\ E-mail: badrusalam3991@gmail.com
}

Diterima: 30 April 2019. Disetujui: 28 Mei 2019. Dipublikasikan: 31 Juli 2019

\begin{abstract}
This research is a development research that aims to produce media product projectile launcher as a simple practical tool of physics on parabolic motion material and to know the feasibility of media projectile launcher as a simple practical tool of physics on parabolic motion material. Problems in this research, among others, is how to develop projectile launcher as a simple practical tool of physics on parabolic motion material and how is the response of learners to media projectile launcher as a simple physics practicum tool on parabolic motion material. . Subjects in this study are class IX SMA N 1 Way Tenong and SMA N 2 Way Tenong. This research is a development research using Research and Development $(R \& D)$ research method that adopt the development of Borg \& Gall that has been modified by sugionoProducts are categorized very feasible based on the validation of material experts with $100 \%$ percentage and based on the validation of media experts with a percentage of $100 \%$, as well as Projectile Launcher media are very interesting to be used as teaching materials based on teacher's assessment to get $100 \%$ score percentage and student's response in limited group trial to get $95 \%$ percentage score for SMA $N 1$ Way Tenong and 92\% for SMA N 2 Way Tenong.
\end{abstract}

Keywords: projectile launcher, practicum tool, parabolic motion.

\begin{abstract}
Abstrak:Penelitian ini merupakan penelitian pengembangan yang bertujuan untuk menghasilkan produk media projectile launcher sebagai alat praktikum sederhana fisika pada materi gerak parabola dan untuk mengetahui kelayakan dari media projectile launcher sebagai alat praktikum sederhana fisika pada materi gerak parabola. Masalah dalam penelitian ini antara lain bagaimanakah mengembangkan projectile launcher sebagai alat praktikum sederhana fisika pada materi gerak parabola dan bagaimanakah respon peserta didik terhadap media projectile launcher sebagai alat praktikum sederhana fisika pada materi gerak parabola. . Subjek dalam penelitian ini adalah kelas IX SMA N 1 Way Tenong dan SMA N 2 Way Tenong. Penelitian ini merupakan penelitian pengembangan menggunakan metode penelitian Research and Development (R\&D) yang mengadopsi pengembangan dari Borg \& Gall yang telah dimodifikasi oleh sugionoProduk yang dihasilkan berkategori sangat layak berdasarkan validasi dari ahli materi dengan presentase $100 \%$ dan berdasarkan validasi dari ahli media dengan presentase $100 \%$, serta mediaProjectile Launchersangatmenarikuntukdijadikanbahanajarberdasarkanpenilaiangurumemperolehpresentaseskor $100 \%$ dan respon peserta didik pada uji coba kelompok terbatas memperoleh skor presentase $95 \%$ untuk SMA N 1 Way Tenong dan 92\% untuk SMA N 2 Way Tenong.
\end{abstract}

(C) 2019 Unit Riset dan Publikasi Ilmiah FTK UIN Raden Intan Lampung

Kata Kunci: projectile launcher, alat praktikum, gerak parabola. 


\section{PENDAHULUAN}

Dunia pendidikan dewasa ini memasuki era dunia media, di mana kegiatan pembelajaran menuntut dikuranginya metode ceramah dan diganti denganpemakaian banyak media, sehingga untuk kegiatan pembelajaran saat iniyang menekankan pada keterampilan proses dan aktif learning, maka kiranya peranan media pembelajaran (yang dalam uraian selanjutnyasering disebut media), menjadi semakin penting untuk digunakan (Nurseto, 2011).

Asyhar (2011) dalam Riki Chandra Wijaya dkk menerangkan bahwa "Media pembelajaran merupakan segala sesuatu yang dapat menyampaikan atau menyalurkan pesan dari suatu sumber secara terencana, sehingga terjadi lingkungan belajar yang kondusif dimana penerimanya dapat melakukan proses belajar secara efisien dan efektif'. Sehingga, media pembelajaran pendidikan memegang peranan yang penting dalam kegiatan pembelajaran sebagai media pendidikan.

Fisika adalah salah satu mata pelajaran yang dihindari oleh siswa. karena dalam pelajaran fisika begitu banyak konsepkonsepsains bersifat fisik yang begitu sulitbagi siswa untuk dipahami secara teoritis.Salah satu materi fisika yang begitu banyakdiajari secara teoritis di pembelajaran fisika ialah gerak parabola sehingga Untuk mengatasikesulitan dalam pembelajaran berdasarkanteori belajar dibutuhkan media pembelajaran(Wijaya, M, \& Kamid, 2014).

\begin{abstract}
Berdasarkan hasil observasi yang telah dilakukan terhadap pendidik maupun peserta didik di SMA N 1 Way Tenong dan SMA N 2 Way Tenong diketahui bahwa masalahyang dihadapi peserta didik dikelas adalah kurang memahami materi yang sedang dijelaskan oleh pendidik karna metode yang digunakan pendidik terbilang monoton atau yang itu itu saja, sehingga dirasa jenuh oleh sebagian besar peserta didik dalam mengikuti proses pembelajaran. Gabel(1994) dalam Edi Daenuri Anwar menjelaskan Permasalahan yang di hadapi guru dalammenyelenggarakan praktikum antara lain kurangnya peralatan dan bahan praktikum dan kurangnya pengetahuam dan keterampilan guru dalam mengelola kegiatan praktikum(Anwar, 2014). Selain itu, tidak adanya asisten yang membantu guru dan terlalu banyaknya siswa sehingga menyulitkan pengaturan proses kegiatan.
\end{abstract}

Projectile launcher merupakan salah satu alat praktikum gerakparabola yang dapat digunakan dalammenentukan jangkauan terjauh, tinggimaksimum, dan waktu tempuh peluru dalam gerak parabola (Wijaya et al., 2014). Melalui pengembangan alat praktikum projectile launcher ini, peneliti memberikan opsi tambahan dalam pengadaaan praktikum gerak parabola.

\section{LANDASAN TEORI}

Kinematika adalah yang merupakan penjelasan mengenai bagaimana benda bergerak (Giancoli, 2001)Sarojo dalam wijayanto,Susilawati menerangkan Beberapa jenis gerak yaitu: 
Gerak Lurus Beraturan

Gerak lurus beraturan adalah gerak benda titik yangmembuat lintasan berbentuk garis lurus dengan sifatbahwa jarak yang ditempuh tiap satuan waktu tetap,baik besar maupun arahnya.

\section{Gerak Lurus Berubah Beraturan}

Gerak lurus berubah beraturan ialah gerak benda titikyang membuat lintasan berbentuk garis lurus dengansifat bahwa jarak yang ditempuh tiap satuan waktutidak sama besar, sedangkan arah gerak tetap.

Disebut peluru(proyektil) adalah suatu benda yang diberi kecepatan awal lalu kemudian menempuh lintasan yang arahnya sepenuhnya dipengaruhi oleh percepatan gravitasi dan hambatan udara (Young, 2002). Sedangkan gerak peluru adalah gerak parabola (Giancoli, 2001).

Posisi benda yang mengalami gerak peluru(dua dimensi) dengan kecepatan awal $v_{o}$,dapatdiberikan dalam masing-masing komponengeraknya, yaitu (Hamdi\&Supardi, 2011) :

$x=\mathrm{v}_{\mathrm{o}} \cos \alpha t$

$y=\mathrm{v}_{\mathrm{o}} \sin \alpha t-\frac{1}{2} \mathrm{gt}^{2}$

\section{METODE PENELITIAN}

Prosedur penelitian pengembangan berpedoman dari desain penelitian pengembangan media instruksional oleh Borg and Gall(Masykur, Nofrizal, \& Syazali, 2017; Nurussaniah \& Nurhayati, 2016; Sohibun \& Ade, 2017; Widiyarini \& Wilujeng, 2015). Produk yang dihasilkan berupa media projectile launcher sebagai alat praktikum sederhana fisika pada materi gerak parabola.
Pengembangan dilakukan dengan metode penelitian dan pengembangan (Research and Development).Model pengembangan pada penelitian ini yaitu model Borg and Gall dalam Sugiyono meliputi: 1). Potensidan Masalah, 2). Menggumpulkan data, 3). Desain Produk, 4). Validasi Desain, 5). Revisi Desain, 6). Uji Coba Produk, 7). Revisi Produk, 8). Uji Coba Pemakaian, 9). Revisi Produk, 10).Produksi Massal.

Dalam penelitian ini dibatasi langkah-langkah penelitian pengembangan dari sepuluh langkah menjadi tujuh langkah di karenakan mengingat waktu yang tersedia dan kesempatan yang terbatas(Latifah, 2015). Subjek penelitian adalah peserta didik kelasIX di SMAN Way Tenongdan SMAN 2 Way Tenong. Data penelitian dikumpulkan dengan menggunakan lembar, lembar respon peserta didik serta analisa data menggunakan skala guttmen.

Angket respon terhadap penggunaan produk. Projectile Launcher sebagai alat praktikum sederhana fisika pada materi gerak parabola sesuai dengan konten pertanyaan. Pengubahan hasil penilaian ahli media, ahli materi, dan guru fisika dari huruf menjadi skor dengan ketentuan pada tabel berikut (Sugiyono, 2010):

Tabel 1. Aturan Pemberian Skor

\begin{tabular}{cc}
\hline Kategori & Skor \\
\hline Ya & 1 \\
Tidak & 0 \\
\hline
\end{tabular}

Angket respon untuk mengetahui kemenarikan media projectile launcher, responden diberikan angket. Mengetahui nilai akhir menggunakan analisis rata-rata butir yang bersangkutan dalam angket yaitu dengan perhitungan 
nilai kelayakan angket tiap aspek dibagidengan banyaknya pernyataan. Hasil skor persentase yang diperoleh daripenelitian diinterpretasikan dalam kriteriatabel 2 (Latifah, 2015):

Tabel 2. Skala Kelayakan Media Projectile Launcher

\begin{tabular}{lc}
\hline $\begin{array}{l}\text { Skor Kelayakan } \\
\text { Media Projectile } \\
\text { Launcher }\end{array}$ & Kriteria \\
\hline $81-100 \%$ & Sangat Layak \\
$61-80 \%$ & Layak \\
$41-60 \%$ & Cukup Layak \\
$21-40 \%$ & kurang Layak \\
$0 \%-21 \%$ & Sangat Kurang layak \\
\hline Nilai keseluruhan dari media \\
projectile launcher sebagai alat \\
praktikum sederhana fisika ini \\
ditentukan dengan menghitung skor \\
rata-rata seluruh kriteria penilaian, \\
kemudian data yang diperoleh \\
diubah menjadi data kualitatif sesuai \\
dengan kriteria penilaian tabel 2. di \\
atas. Data yang telah diperoleh \\
kemudian dihitung \\
memperoleh nilai ahir dengan \\
menggunakan rumus : \\
\% $5 S=\frac{\overline{S S}}{S_{m}} x 100 \%$ \\
Keterangan : \\
$\overline{S S}=$ Skor rata-rata \\
$S m=$ Skor maksimal
\end{tabular}

\section{HASIL DAN PEMBAHASAN}

Tahapan awal yang dilakukan dalam perencanaan produk awal adalah melakukan observasi kesekolah-sekolah. Hasil dari observasi yang dilakukan diketahui bahwa penggunaan minimnya penggunaan alat praktikum dalam pembelajaran sehingga alat praktikum sangat dibutuhkan dalam pembelajaran. Langkah awal yang dilakukan dalam pembuatan media projectile launcher sebagai alat praktikum sederhana fisika diawali dengan mengumpulkan alat dan bahan. Selanjutnya alat dan bahan dirangkai menjadi sebuah media projectile launcher sebagai alat praktikum sederhana fisika pada materi gerak parabola.

Produk tersebut diharapkan dapat menjadi dasar dalam mengembangkan alat praktikum. Alat praktikum merupakan salah satu media pembelajaran yang dapat digunakan pendidik dalam melaksanakan kegiatan pembelajaran dan peserta didik dapat lebih mudah memahami konsep pembelajaran dengan baik.

Produk yang telah dikembangkan kemudian divalidasi oleh beberapa ahli sebelum diuji cobakan di lapangan. Validasi dilakukan oleh 3 ahli materi dan 3 orang ahli media yang ahli dibidangnya.

a. Hasil validasi oleh ahli materi

Hasil validasi ahli materi mencakup 4 aspek penilaian yaitu: kesesuaian alat praktikum dengan materi, keterkaitan alat praktikum dengan materi, nilai pendidikan dan konten fisika. Hasil penilaian dari tiga ahli materi mendapatkan nilai rata-rata sebesar 1 dengan kriteria kelayakan sebesar $100 \%$. Kategori penilaian adalah "sangat layak", hal ini berarti media projectile launcheryang dikembangkan sudah sesuai dengan materi pembelajaran fisika dan layak digunakan dalam pembelajaran.

b. Hasil validasi ahli media tahap I Pada validasi yang dilakukan oleh ahli media projectile launcher yang dikembangkan sudah layak tetapi ada beberapa komponen yang harus diperbaiki. Hal ini terlihat dari hasil penilaian yang 
dilakukan oleh validator ahli media. Validasi ahli media ini mencakup 5 aspek penilaian yaitu: efesiensi alat praktikum, keakuratan alat praktikum, estetika, ketahanan alat praktikum dan kemanan alat praktikum bagi peserta didik. Hasil penilaian pada tahap I ini mendapatkan persentase kelayakan sebesar 78 $\%$ dengan rata-rata nilai sebesar 0,77 dengan katagori "layak".

c. Hasil validasi ahli media tahap II Setelah produk direvisi sesuai dengan saran dan masukan validator,media projectile launcheryang dikembangkan sudah sangat layak digunakan. Hasil validasi tahap II mendapatkan persentase kelayakan sebesar $100 \%$ dengan katagori "sangat layak".

d. Uji Coba Produk

Uji coba meliputi uji coba kelompok terbatas terhadap media projectile launcher. Uji coba ini diawali dengan menjelaskan materi secara singkat, kemudian mengarahkan peserta untuk merangkai dan kemudian diujicobakan oleh peserta secara mandiri. Media projectile launcherini telah diengkapi dengan panduan praktikum, lembar hasil praktikum dan manual sehingga dapat memudahkan peserta didik saat melakukan uji coba secara mandiri. Setelah uji coba, selanjutnya peserta didik diminta untuk mengisi angket tanggapan terhadap media projectile launcher. Dalam uji coba produk ada seorang guru atau pendidik yang juga diminta untuk mengisi angket tanggapan pendidik terhadap media projectile launcher.

Angket peserta didik terdiri dari 4 aspek penilaian. Pada uji coba kelompok terbatas yang dilakukan di SMA N 1 Way Tenongkelayakan media projectile launchermedapatkan persentase sebesar $95 \%$ dan rata-rata nilai sebesar 0,95 dengan kategori "sangat layak". Pada uji coba kelompok terbatas yang dilakukan di SMA N 2 Way Tenong, kelayakan media projectile launcher mendapatkan persentase sebesar $92 \%$ dan nilai rata-rata sebesar 0,92 dengan kategori "sangat layak". Gabungan hasil rata-rata uji coba kelompok terbatas dari kedua sekolah tersebut kelayakan media projectile launchermendapat persentase kelayakan sebesar $92 \% \%$ dengan kategori sangat layak. Berikut adalah grafik Data hasil uji coba kelompok terbatasdi SMAN 1 Way Tenong :

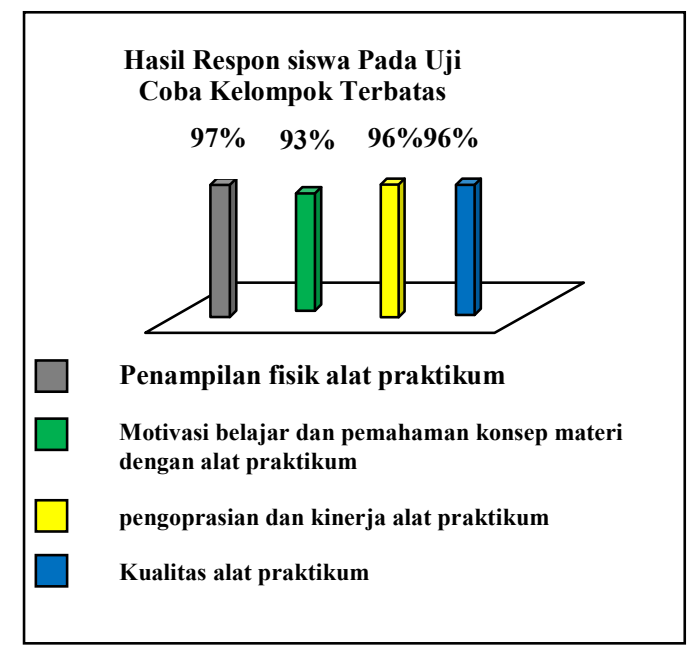

Gambar 1. Grafik Data hasil uji coba kelompok terbatas di SMAN 1 Way Tenong.

Berikut adalah grafik Data hasil uji coba kelompok terbatas di SMAN 2 Way Tenong : 


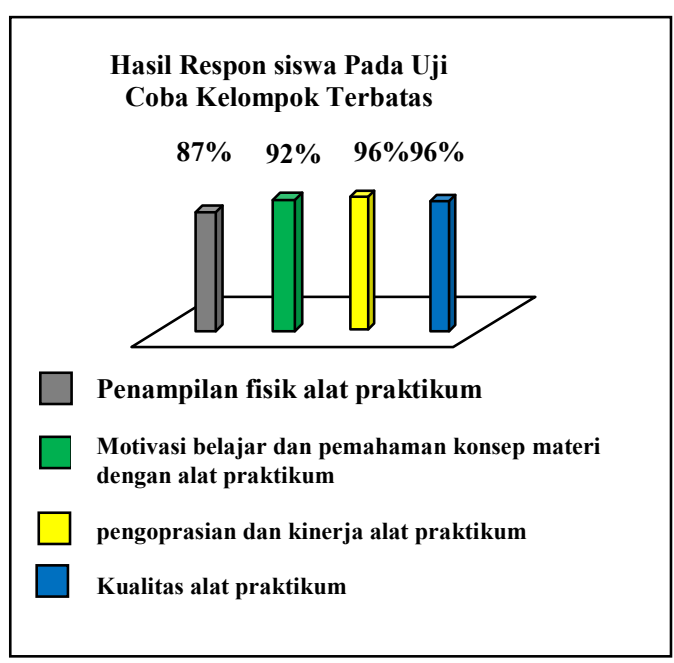

Gambar 2. Grafik Data hasil uji coba kelompok terbatas di SMAN 2 Way Tenong. Produk yang berhasil dikembangkan ini berupa media projectile launcher sebagai alat praktikum sederhana fisika pada materi gerak parabolauntuk meningkatkan motivasi belajar siswa pada materi gerak parabola. media projectile launcher ini digunakan untuk menjelaskan materi-materi tentang gerak parabola. Setelah melalui tahap validasi dari beberapa dosen yang ahli dibidangnya serta uji coba yang dilakukan,media projectile launcherini dinyatakan "sangat layak" sehingga tidak perlu direvisi kembali.

\section{KESIMPULAN}

Hasil dari penelitian dan pengembangan media projectile launcher sebagai alat praktikum sederhana fisika pada materi gerak parabola dapat disimpulkan bahwa media projectile launcher sebagai alat praktikum sederhana fisika pada materi gerak parabola dikembangkan malalui 7 tahapyaitu: potensi dan masalah, mengumpulkan informasi, desain produk, validasi desain, revisi desain, uji coba produk, dan revisi produk dengan menghasilkan media projectile launcher sbagai alat praktikum sederhana fisika pada materi gerak parabola dalam bentuk alat praktikum sederhana yang dapat di operasikan dengan mudah karena telah dilengkapi dengan buku panduan praktikum, buku manual dan video pembelajaran. Media projectile launcher sebagai alat praktikum sederhana fisika pada materigerak parabola yang dikembangkan telahdiujikan melalui angket validasi media dengan ratarata penilaian sebesar $100 \%$ dikategorikan sangat layak, angket validasi materi dengan rata-rata penilaian sebesar $\quad 100 \%$ dikategorikan sangat layak dan uji respon peserta didik pada ujicoba produk terbatas di SMAN 1 Way Tenong dengan persentase penilaian sebesar 95\% dan di SMAN 2 Way Tenong dengan persentase penilaian sebesar $92 \%$, sehingga pada ujicoba tersebut masuk dalam sangat layak digunakan.

\section{DAFTAR PUSTAKA}

Anwar, E. D. (2014). Pelatihan Pembuatan Alat-Alat Praktikum IPA Fisika Bagi Guru IPA SMP/MTS Swasta SeKecamatan Winong Kab. Pati.

Giancoli, D. C. (2001). Fisika (Edisi Keli). Jakarta: Erlangga.

Latifah, S. (2015). Pengembangan Modul IPA Terpadu Terintegrasi Ayat-Ayat AlQur'an Pada Materi Air Sebagai Sumber Kehidupan. Jurnal Ilmiah Pendidikan Fisika AlBiruni, 4(2), 155.

Masykur, R., Nofrizal, \& Syazali, M. (2017). Pengembangan Media Pembelajaran Matematika 
dengan Macromedia Flash. AlJabar: Jurnal Pendidikan Matematika, 8(2).

Nurseto, T. (2011). Membuat Media Pembelajaran yang Menarik. Ekonomi \& Pendidikan, 8(1), 19-35.

Nurussaniah, \& Nurhayati. (2016). Pengembangan Penuntun Praktikum Fisika Dasar 1 Berbasis Guided Inquiry Untuk Meningkatkan Kemampuan Berpikir Kritis Mahasiswa. Priosiding Seminar Nasional Fisika (E-Journal), V, 63-68.

Sohibun, \& Ade, F. Y. (2017). Pengembangan Media Pembelajaran Berbasis Virtual Class Berbantuan Google Drive. Pengembangan Media Pembelajaran Berbasis Virtual Class Berbantuan Google Drive, 02(2), 121-129.

Sugiyono. (2010). Metode Penelitian kuantitatif, kualitatif dan $R \& D$. Bandung: Alfabeta.

Widiyarini, A., \& Wilujeng, I. (2015). Pengembangan LKS IPA berbasis scientific approach untuk mengoptimalkan learning outcome siswa MTs kelas VII. Jurnal Pendidikan Matematika Dan Sains, 3(2), 169-181.

Wijaya, R. C., M, D., \& Kamid. (2014). Pengembangan Media Pembelajaran Fisika Projetile Launcher Sebagai Alat Praktikum Fisika Pada Materi Gerak Parabola Fisika Kelas XI IPA. EDUSAINS.

Young, A. F. (2002). Fisika Universitas Edisi Kesepuluh Jilid 1. Jakarta: Erlangga. 